\title{
Phytoplankton production in the Delaware Estuary: temporal and spatial variability
}

\author{
Jonathan R. Pennock \& Jonathan H. Sharp
}

College of Marine Studies, University of Delaware, Lewes, Delaware 19958, USA

\begin{abstract}
Phytoplankton production in the Delaware Estuary (USA) was measured over several seasonal cycles (1980-1985). Seasonal variability in daily areal production $\left(\int \mathrm{P} ; \mathrm{g} \mathrm{C} \mathrm{m}^{-2} \mathrm{~d}^{-1}\right.$ ) was directly related to chlorophyll concentrations in the upper estuary, ranging from a maximum of $1.1 \mathrm{~g} \mathrm{C}$ $\mathrm{m}^{-2} \mathrm{~d}^{-1}$ in summer to a minimum of $<0.1 \mathrm{~g} \mathrm{C} \mathrm{m}^{-2} \mathrm{~d}^{-1}$ in winter. In the mid and lower estuary, maximum $\int P$ occurred during 2 periods: at the estuary mouth $\left(4.2 \mathrm{~g} \mathrm{C} \mathrm{m}^{-2} \mathrm{~d}^{-1}\right)$ during summer in the presence of low phytoplankton biomass $\left(2\right.$ to $\left.10 \mu \mathrm{g} \mathrm{Chl} \mathrm{l}^{-1}\right)$, and in mid-estuary $\left(2.6 \mathrm{~g} \mathrm{C} \mathrm{m}^{-2} \mathrm{~d}^{-1}\right)$ during the spring diatom bloom (50 to $60 \mu \mathrm{g} \mathrm{Chl}{ }^{-1}$ ). Despite the occurrence of maximum nutrient concentrations in the freshwater region, highest $\int \mathrm{P}$ and $90 \%$ of the annual production occurred in the lower estuary, down-stream from the turbidity maximum. The presence of the turbidity maximum immediately downstream from major anthropogenic nutrient sources restricts phytoplankton growth, and limits biomass accumulation below nuisance levels. Annual production for the 1981-1985 period averaged $307 \mathrm{~g} \mathrm{C} \mathrm{m}^{-2}$ and displayed marked inter-annual variability. Light availability is the predominant regulator of production in the estuary. Although growth was light-limited, neither chlorophyll specific production nor the light intensity at which photosynthesis saturates was related to the mean light intensity in the mixed surface-layer. These results suggest that photoadaptive response times are slower than the vertical mixing rate and that photoadaptation is of minor significance to overall production in the system.
\end{abstract}

\section{INTRODUCTION}

Few studies of estuaries provide a comprehensive examination of temporal and spatial variability in phytoplankton production, and attempt to delineate the factors causing this variability (e.g. Joint \& Pomroy 1981, Cole \& Cloern 1984). Estuarine phytoplankton production is often considered to be dependent on either nutrient or light availability (Riley 1967, Williams 1972, Fisher et al. 1982). It has, however, been difficult to relate variability in these factors to variability in production.

In estuaries where inorganic nutrient concentrations are low, phosphorus (Jaworski 1981) and, more often, nitrogen (Boynton et al. 1982) have been identified as factors that control phytoplankton production. The more commonly found relation between nitrogen concentration and estuarine phytoplankton production is consistent with the observation that nitrogen limits phytoplankton production in coastal waters (Ryther \& Dunstan 1971, Sharp \& Church 1981). There is not, however, a direct relation between production and inorganic nutrient concentrations in these estuarine systems. This lack of relation is caused by several factors, but is primarily the result of heterotrophic nutrient regeneration that may support high phytoplankton production rates even at times when nutrient concentrations are low.

In estuaries where nutrient concentrations may be elevated by inputs from both natural run-off and anthropogenic sources, light becomes the predominant regulator of primary production (Bruno et al. 1980, Joint \& Pomroy 1981, Boynton et al. 1982, Cole \& Cloern 1984). Under nutrient-saturated conditions, restricted light availability may alter phytoplankton production in 2 ways: (1) by regulating the maximum attainable biomass in the system (Wofsy 1983, Pennock 1985); (2) by stimulating physiological adaptation to low light conditions (Harris 1978, Falkowski 1980). Both of these factors would be expected to show temporal and spatial variability that would affect production in the system.

Boynton et al. (1982) have summarized seasonal patterns of primary production in a number of estuaries. They found that, in general, the maxima in both phytoplankton biomass and productivity occurred 
during warmer seasons of the year and that the magnitude of these maxima were most closely related to nitrogen availability. However, they were unable either to define a general pattern explaining bloom occurrence or to generalize about spatial patterns of estuarine production because of the diverse nature of the systems examined. Boynton et al. (1982) note that there are few good long-term records of estuarine primary productivity. In the San Francisco Bay system, more detail is available over both temporal and spatial scales than for most systems (Cloern 1984, Cole \& Cloern 1984, Cloern et al. 1985). There, Cloern et al. (1985) were able to relate the spring bloom to freshwater discharge in South Bay, and relate productivity with light availability in the river-dominated Suisun Bay. To be able to develop sufficient understanding of spatial and temporal variability in an estuary, it is clear that such sampling throughout the full geographic extent of the estuary and over sufficient time is necessary to delineate both seasonal and inter-annual patterns.

In this paper, we use the Delaware Estuary as an example of a nutrient-rich system (Sharp et al. 1982) in which light availability regulates biomass (Pennock 1985). Seasonal variation in phytoplankton productivity is described over a 5 yr period and related to light and nutrient availability. Annual areal productivity is estimated, and inter-annual variability in phytoplankton productivity is presented. In addition, physiological parameters associated with photosynthesis (chlorophyll specific production, the initial slope of the $\mathrm{P} / \mathrm{I}$ curve, and the light intensity at which photosynthesis saturates), are examined to assess the importance of photoadaptation to production in the estuary.

\section{STUDY AREA AND METHODS}

Samples were taken during 32 cruises of 1 to $4 \mathrm{~d}$ duration on the Delaware Estuary from October 1980 through August 1985 aboard R/V Cape Henlopen. During the 1981-82 and 1985 periods, cruises were conducted at near monthly intervals with increased sampling during the spring bloom. Sampling during 1983-84 was less frequent but served to describe interannual variations during key periods of the year. Sampling stations, from the freshwater region near Philadelphia, to the mouth of the estuary near Lewes, Delaware, were determined on the basis of salinity (Fig. 1). On each cruise, between 10 and 20 stations were occupied along the main axis of the estuary over a 10 to $15 \mathrm{~h}$ period. Additional cross-estuary transects

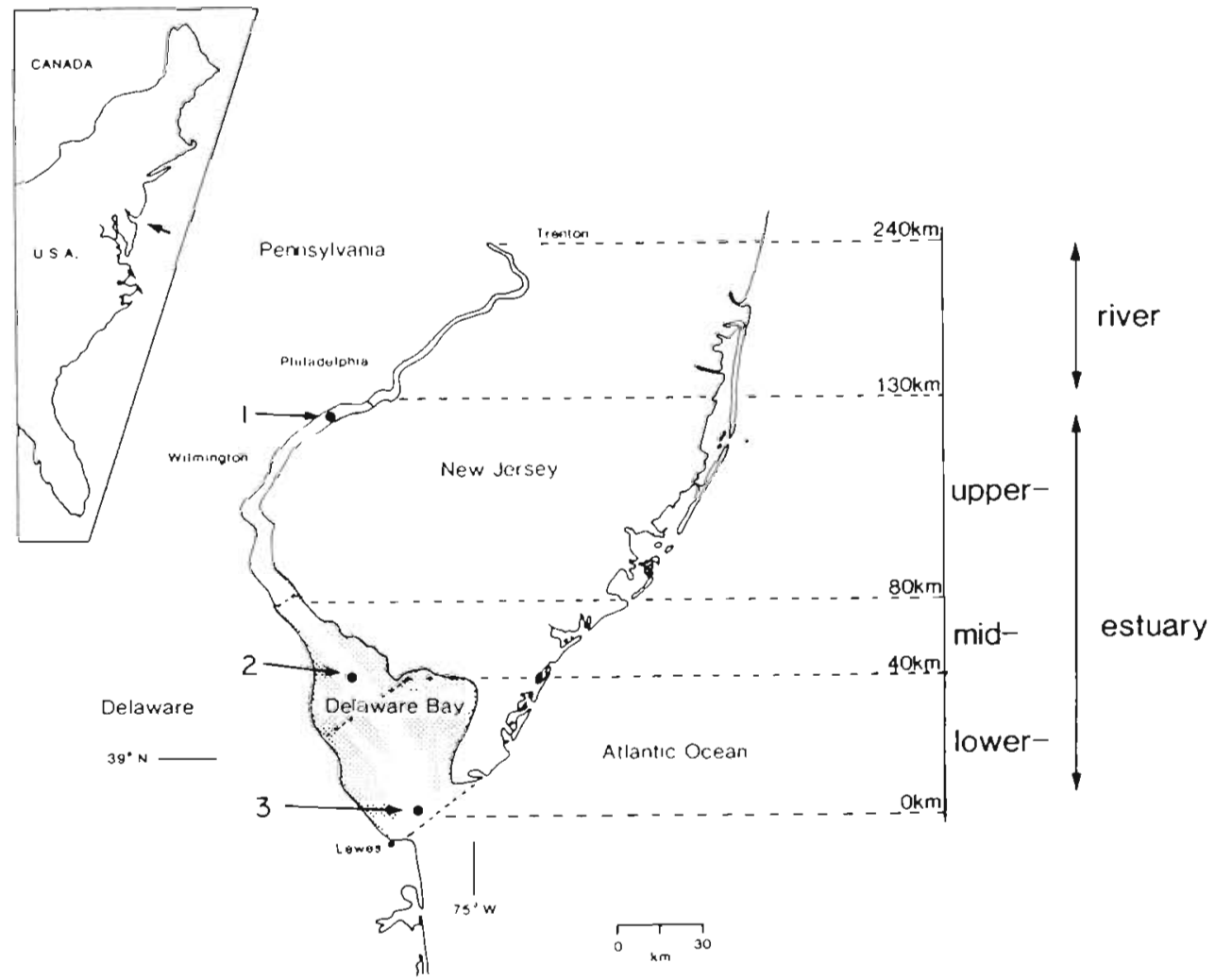

Fig. 1. Delaware Estuary and watershed on U.S. East Coast. Distances upstream from mouth of estuary are shown at right. Shoal regions in lower estuary are shaded. Specifically referenced stations at beginning of salinity gradient (SO), mid-bay (CL), and near mouth of bay (BR) shown respectively as 1,2 , and 3 
that traversed the extensive shoals in the lower estuary were sampled in 1982-84.

Vertical profiles of salinity, temperature, fluorescence, and turbidity (beam attenuation) were determined on station using a Neil-Brown-Mark III CTD system fitted with an in vivo fluorometer and transmissiometer. The diffuse attenuation coefficient $(\mathrm{k})$ for photosynthetically active radiation (PAR) was determined using a Biospherical Instruments QSR-100 submersible probe. Incident daily PAR was recorded with a QSR-250 integrating quantum meter. Samples for productivity measurements and supporting chemical analyses were obtained near the surface (1 to $2 \mathrm{~m}$ ) using 101 Niskin bottles. Ancillary data collected concurrently with productivity experiments included: chlorophyll a via fluorometry (Strickland \& Parsons 1972), total alkalinity (Edmond 1970), salinity via induction salinometer, dissolved oxygen by Winkler titration (Carpenter 1965), and dissolved inorganic nutrients $\left(\mathrm{NH}_{4}^{+}, \mathrm{NO}_{3}^{-}, \mathrm{NO}_{2}^{-}, \mathrm{PO}_{4}^{3-}\right.$, and $\left.\mathrm{SiO}_{2}\right)$ using modified colorimetric methods (Sharp et al. 1982).

Carbon production methods were modified from the general procedures of Eppley \& Sharp (1975). Within 20 min of collection, whole water samples were transferred (under low light) to $65 \mathrm{ml}$ bottles and $2 \mu \mathrm{Ci}$ of $\left[{ }^{14} \mathrm{C}\right] \mathrm{HCO}_{3}$ was added. Time zero $\left(\mathrm{T}_{0}\right)$ bottles were filtered immediately, and simulated in situ incubations (Head 1976) were started in a deck incubator cooled by surface seawater. Incubations used 6 light levels $(100$, $60,30,12,3.3$ and $1.1 \%$ of incident PAR) obtained with neutral density screens. After $24 \mathrm{~h}$, incubations were terminated by filtering the particulate matter onto Whatman $\mathrm{GF} / \mathrm{C}$ filters at reduced $(<350 \mathrm{~mm} \mathrm{Hg}$ ) vacuum and rinsing them with filtered seawater. Wet filters were immediately placed in scintillation vials containing $7 \mathrm{ml}$ of Aquasol-2 and later counted on a Packard Tri-Carb liquid scintillation counter using the external standard ratio determination of efficiency.

The potential influence of incubation conditions, including: (1) trace metal contamination of isotope stocks and incubation bottles (Fitzwater et al. 1982), (2) effect of bottle size and enclosure, and (3) length of the incubation period (Carpenter \& Lively 1980, Peterson 1980) were tested during preliminary experiments. No significant difference was detected between incubations conducted with 'clean' technique (Fitzwater et al. 1982) and our 'standard' techniques in which glass bottles are cleaned with $10 \% \mathrm{HCl}$ followed by rinses with deionized water. Bottle size effects were also shown to be negligible for volumes between 20 and $1000 \mathrm{ml}$ (Pennock 1983).

Daily areal phytoplankton production, $\int \mathrm{P}\left(\mathrm{g} \mathrm{C} \mathrm{m}^{-2}\right.$ $\mathrm{d}^{-1}$ ), was estimated at each station by fitting the productivity measured at each of the 6 light levels ( $m g \mathrm{C}$ $\mathrm{l}^{-1} \mathrm{~d}^{-1}$ ) and light data (as described by the diffuse attenuation coefficient $[\mathrm{k}]$ ) to a hyperbolic tangent function (Platt \& Jassby 1976). Annual areal production rates were obtained by partitioning $\int \mathrm{P}$ estimates for each cruise into geographically fixed subsections ( $5 \mathrm{~km}^{2}$ centered on the main channel) of the estuary to obtain an area-weighted average $\int P$ for each sampling date. These values were time-weighted to obtain average monthly production estimates for the $5 \mathrm{yr}$ period and then summed over the annual cycle.

Hourly values for maximum chlorophyll-specific production $\left(\mathrm{P}_{\mathrm{m}}^{\mathrm{B}}\right)$, the initial slope of the P/I curve $\left(\alpha^{\mathrm{B}}\right)$, and the light intensity at which photosynthesis saturates $\left(I_{k}\right)$ were estimated by dividing $24 \mathrm{~h}$ production estimates at each of 6 light levels by the length of the light period during that day and fitting the data to a $\mathrm{P} / \mathrm{I}$ curve (Platt \& Jassby 1976). In contrast to instantaneous measurements at a constant light intensity, $24 \mathrm{~h}$ incubations integrate diel variations, respiratory loss, and variation in ambient light intensity. For this reason, the estimates obtained from $24 \mathrm{~h}$ incubations are referred to as $\mathrm{P}_{\mathrm{m}: 24]}^{\mathrm{B}}\left(\mu \mathrm{g} \mathrm{C}[\mu \mathrm{g} \mathrm{Chl} \mathrm{h}]^{-1}\right), \alpha_{[24 \mid}^{\mathrm{B}}(\mu \mathrm{g} \mathrm{C}$ $\left.[\mu \mathrm{g} C h] \mathrm{h}]^{-1}\left[\mu \mathrm{E} \mathrm{m} \mathrm{m}^{-2} \mathrm{~s}^{-1}\right]^{-1}\right)$, and $\mathrm{I}_{\mathrm{k} \mid 24]}\left(\mu \mathrm{E} \mathrm{m}^{-2} \mathrm{~s}^{-1}\right)$ to distinguish them from the physiological parameters described by Platt \& Jassby (1976). For the comparative purposes of this analysis, these parameters are considered analogous to the instantaneous parameters. A discussion and justification of the comparability of these methods can be found in Pennock (1983).

\section{RESULTS AND DISCUSSION}

Phytoplankton production $\left(\int \mathrm{P}\right)$ in the Delaware Estuary exhibited marked spatial and temporal variability that followed an annual sequence that was generally repeatable from year to year (Fig. 2). In examining the factors that regulate this annual sequence in productivity, it is important to differentiate between those factors that influence temporal variability, such as incident irradiance and temperature, and those that influence spatial variability, such as suspended sediment distribution and nutrient concentrations.

\section{Temporal variation in phytoplankton production}

In temperate estuaries, phytoplankton production is often thought to follow a seasonal progression that parallels the annual cycle of irradiance, particularly under conditions when nutrients are not limiting (Boynton et al. 1982). Such a progression was evident in both the riverine and lower regions of the Delaware Estuary, as can be seen in 5 yr productivity records at select stations in these regions (Stations $\mathrm{SO}$ and BR, respectively; Fig. 3). 

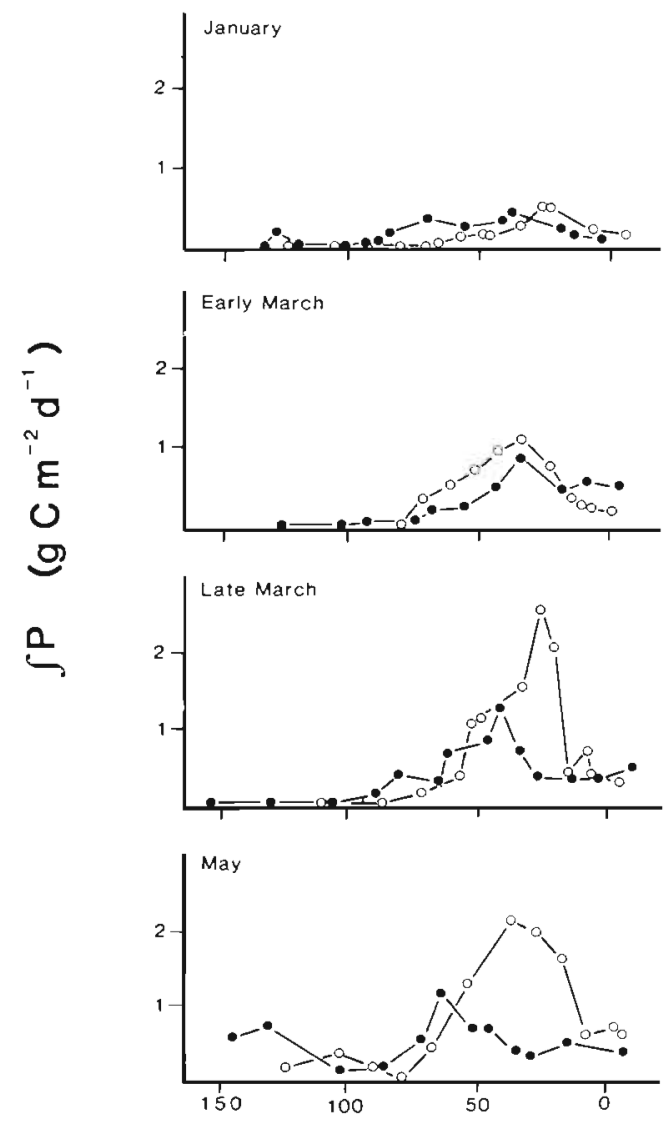
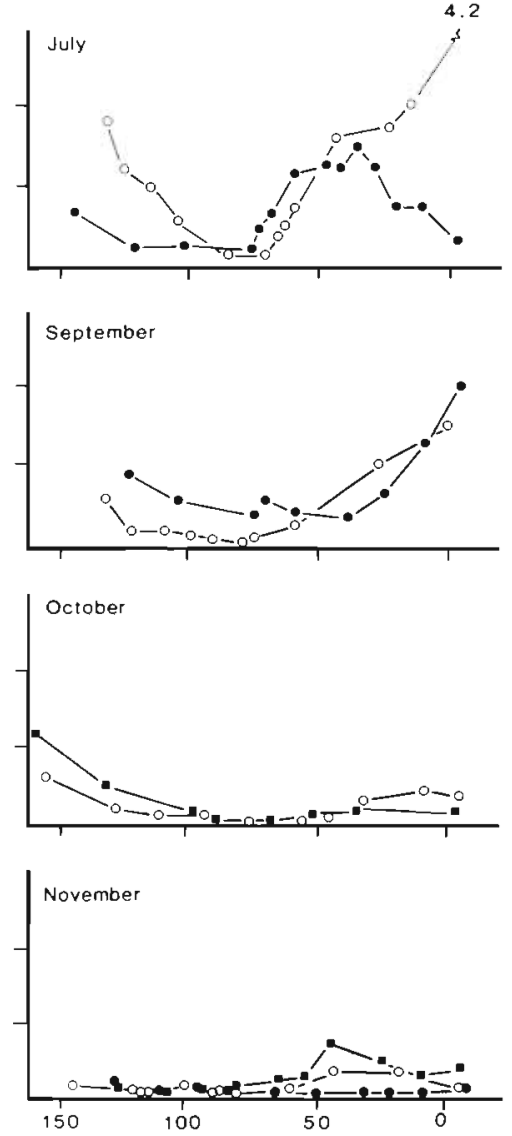

\section{Distance Upstream $\quad(\mathrm{km})$}

Fig. 2. Areal production of phytoplankton $\left(\int P\right)$ in the Delaware Estuary for 8 sampling times over the year as a function of distance up the estuary from the mouth. (•) $1980 ;(\bullet) 1981 ;($ ) 1982

In the riverine region, $\int \mathrm{P}$ ranged from of $0.1 \mathrm{~g} \mathrm{C} \mathrm{m}^{-2}$ $\mathrm{d}^{-1}$ during winter to $1.8 \mathrm{~g} \mathrm{C} \mathrm{m}^{-2} \mathrm{~d}^{-1}$ during summer. During winter, the riverine region was characterized by a relatively long period $(\sim 4 \mathrm{mo})$ of low $\int \mathrm{P}$. This pattern appeared to be caused by a combination of low irradiance and low temperature that suppressed the growth of the freshwater phytoplankton population. As a result of warmer temperatures and increased irradiance, $\int P$ in the riverine region increased during May and remained elevated throughout summer. Despite higher productivity during this period, however, maximum $\int P$ continued to be regulated by light availability in the surface mixed-layer (Wofsy 1983, Pennock 1985) and nutrient concentrations were unaffected by phytoplankton uptake (Pennock 1983, Lipschultz et al. 1985).

A temporal sequence similar to that in the riverine region existed in the lower estuary (Fig. 3; Station BR), although both minimum and maximum rates of $\int P$ were greater than in the riverine region of the estuary During winter, $\int \mathrm{P}$ seldom fell below $0.3 \mathrm{~g} \mathrm{C} \mathrm{m}^{-2} \mathrm{~d}^{-1}$ in the lower estuary despite low temperatures $\left(<1^{\circ} \mathrm{C}\right)$. When periods of low $\int \mathrm{P}$ did occur, they were never of sustained duration as a result of intermittent diatom flowerings. These blooms were dominated by Skeletonema costatum, Leptocylindrus sp., and Thallassiosira sp. During summer, $\int \mathrm{P}$ in the lower estuary attained the maximum rates observed in the estuary (>2.5 $\left.\mathrm{g} \mathrm{C} \mathrm{m}^{-2} \mathrm{~d}^{-1}\right)$, primarily during nannoplankton blooms dominated by Cryptomonas sp.

In contrast to temporal sequences for the riverine and lower estuarine regions, $\int \mathrm{P}$ in mid-estuary reached a maximum $\left(>2 \mathrm{~g} \mathrm{C} \mathrm{m}^{-2} \mathrm{~d}^{-1}\right)$ during spring rather than summer (Fig. $2 \& 3$; Station CL). This maximum in $\int P$ was the result of a spring diatom bloom, dominated by Skeletonema costatum, that reached chlorophyll concentrations $>50 \mu \mathrm{g} \mathrm{l}^{-1}$. Pennock (1985) has shown that this bloom results from an increase in the average light intensity of the mixed surface-layer that is caused by vertical stratification during the spring freshet. The presence of a spring phytoplankton bloom is certainly not unique to the Delaware Estuary; 

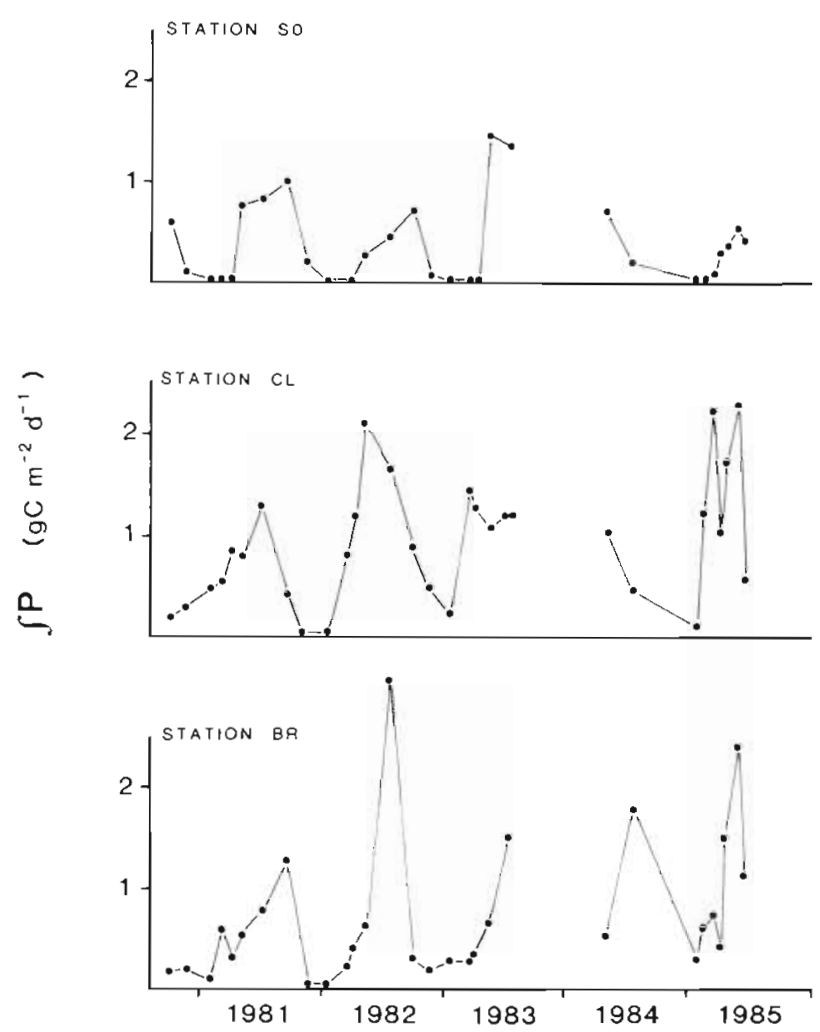

Fig. 3. Areal production of phytoplankton in 3 regions of the Delaware Estuary from October 1980 through August 1985. The 3 regions are respectively: Station SO at head of salinity gradient (130 km from mouth), a mid-bay station (CL) geographically near Crossledge Light House ( 35 to $50 \mathrm{~km}$ ), and Station BR (10 km from mouth). See Fig. 1 for approximate locâtions

however, hydrodynamic control of bloom formation has only been shown for a few estuaries (Tyler \& Seliger 1978, Cloern 1979). The importance of hydrodynamic factors is further observed during summer when the absence of stratification inhibits bloom formation in the mid-estuary (Pennock 1985) and results in $\int \mathrm{P}$ rates that are lower than those observed during spring. Hydrodynamic control of biogeochemical processes in the Delaware has been further analyzed elsewhere with respect to both microbiological and chemical processes (Sharp et al. 1986).

In nutrient-enriched estuaries, such as the Delaware, non-summer blooms may be responsible for a significant portion of the overall annual production because sufficient inorganic nutrient concentrations are available to support large increases in phytoplankton biomass. As a result, even though biomass specific production rates $\left(\mathrm{P}_{\mathrm{m}}^{\mathrm{B}}\right)$ may be low, $\int \mathrm{P}$ may be high. Under nutrient conditions similar to those in the Delaware Estuary, Cole \& Cloern (1984) found that maximum $\int \mathrm{P}$ in the San Francisco Estuary occurred during spring biomass maxima stimulated by a narrow range of river discharge rate.

\section{Spatial variation in phytoplankton production}

The general temporal sequence of $\int P$ described above is altered spatially in the estuary as environmental factors such as suspended sediment concentration, depth of the water column and nutrient concentration vary. The most persistent characteristic of $\int P$ along the longitudinal axis of the Delaware Estuary is the low production observed in the turbidity maximum, 75 to $110 \mathrm{~km}$ upstream from the mouth of the estuary (Fig. 2). In this region, suspended sediment concentrations ranged from 60 to $200 \mathrm{mg} \mathrm{l}^{-1}$, resulting in much reduced light availability in the surface mixed-layer. Upstream from the turbidity maximum, $\int P$ was dependent on seasonal variability in the production of the freshwater phytoplankton population. During the productive period in the upper estuary (May to Oct) there was a consistent decrease in $\int \mathrm{P}$ from the riverine region (150 $\mathrm{km}$ upstream) to the turbidity maximum (Fig. 2). The decrease in $\int \mathrm{P}$ appeared to be caused both by decreased light levels found in the turbidity maximum and by stress encountered by freshwater phytoplankton advected into brackish waters. These conclusions are supported by the observation of a net loss in both chlorophyll and freshwater phytoplankton cell numbers (Pennock 1985), and a decrease in chlorophyll specific production $\left(\mathrm{P}_{\mathrm{m}}^{\mathrm{B}}\right)$ in this region (see below).

Downstream of the turbidity maximum, in mid-estuary (35 to $70 \mathrm{~km}$ upstream), $\int \mathrm{P}$ follows the seasonal progression determined by the formation and dissipation of the phytoplankton spring bloom. As discussed above, the onset of vertical stratification stimulates phytoplankton growth beginning in late winter, resulting in increased biomass and high $\int P$ from early March through May. In the absence of vertical stratification, suspended sediment concentrations of 7 to $20 \mathrm{mg} \mathrm{l}^{-1}$ would be sufficient to limit phytoplankton growth (Pennock 1985). Termination of the bloom in April and May is most likely the result of several coincident processes, including: a return to vertical mixing of the water-column, exhaustion of phosphate and silicate (Sharp et al. 1984), and increased grazing by zooplankton (Herman et al. 1983).

The lower estuary (0 to $35 \mathrm{~km}$ upstream) is characterized by high $\int \mathrm{P}$ during late summer when water temperature is at a maximum $\left(25\right.$ to $28^{\circ} \mathrm{C}$ ), high incident irradiance, and low suspended sediment concentrations. Under these conditions, nannoplankton dominate the phytoplankton assemblage, and $\mathrm{P}_{\mathrm{m}}^{\mathrm{B}}$ attains its annual maximum (see below). Lateral distribution of $\int \mathrm{P}$ across the lower estuary is also regulated by light availability (Fig. 4). Primarily as a result of wind and tidal resuspension of bottom sediments, suspended sediment concentrations in the shallow shoal regions 

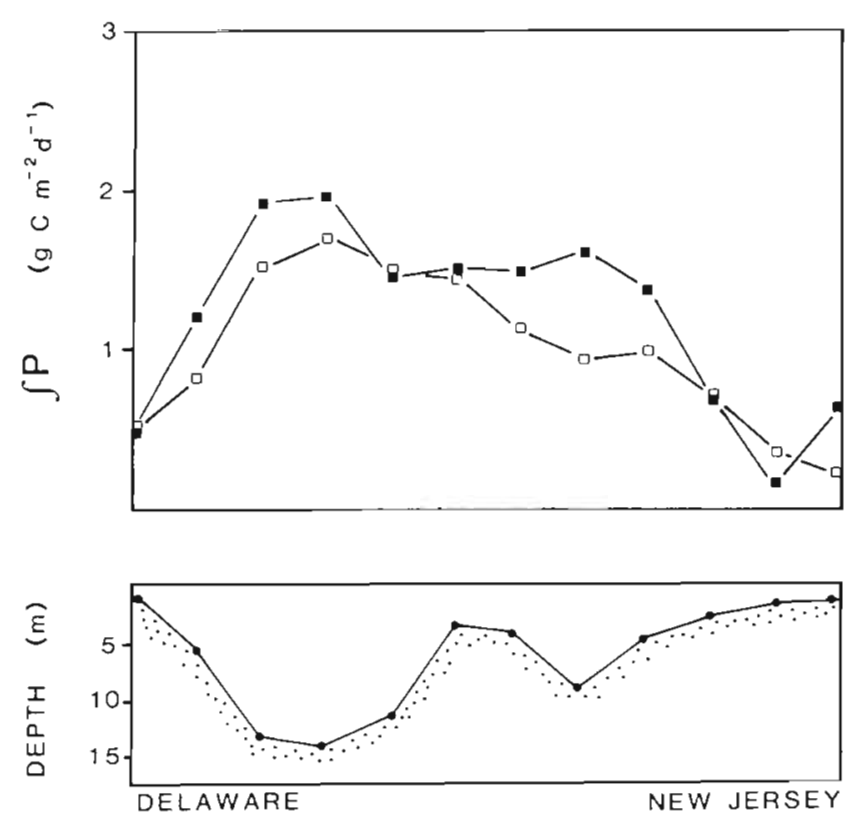

Fig. 4. Areal production of phytoplankton $\left(\int P\right)$ in the Delaware Estuary along a cross-bay transect. Plotted values are averages from sampling in springs ( $\square$ ) and summers ( $\square$ ) of 1982 and 1983. Bathymetry shown in insert beneath plot

range as high as $180 \mathrm{mg} \mathrm{l}^{-1}$, as compared with concentrations $<10 \mathrm{mg} \mathrm{l}^{-1}$ in the central channel. These conditions limit $\int P$ over the shoals and result in a pattern in which $\int P$ is at a maximum in the deeper channels.

Summarizing over both space and time, the distribution of $\int \mathrm{P}$ (Fig. 5a) is determined primarily by the factors that regulate light availability and phytoplankton biomass. Light availability in the water-column is determined by ambient light intensity, suspended sediment concentration, and vertical stratification. Of these factors, the location of the turbidity maximum (Fig. 5b) has the most profound impact on the spatial distribution of $\int P$ in the estuary. The observed variability in phytoplankton biomass (Fig. 6a) also depends on light availability (Pennock 1985) and strongly influences $\int \mathrm{P}$. The influence of biomass on production in the estuary can be seen in the parallel behavior of chlorophyll $a$ and the light-saturated photosynthetic rate $\left(P_{m}\right)$ in the estuary (Fig. 6a \& b, respectively).

Examination of the relation between $\int \mathrm{P}$ and a composite parameter representing both biomass and light availability, B $I_{0} / \mathrm{k}$ (Cole \& Cloern 1984), provides insight into the importance of chlorophyll concentration (B), ambient light intensity $\left(\mathrm{I}_{0}\right)$ and water-column light attenuation ( $k$ ) to $\int P$ in the estuary (Fig. 7 ). For the Delaware, the relation between $\int \mathrm{P}$ and $\mathrm{B} \mathrm{I}_{0} / \mathrm{k}$ shows a marked difference between seasons. For nonsummer periods, $\mathrm{B} \mathrm{I}_{0} / \mathrm{k}$ describes $68 \%$ of the variation in $\int \mathrm{P}$, suggesting that light availability and biomass are the key variables regulating $\int P$. This observation is consistent with our understanding of the factors that control chlorophyll distributions (Pennock 1985). In summer, however, B $I_{0} / \mathrm{k}$ explains only $42 \%$ of the variation in $\int P$, and the slope of the relation is much greater. The increased slope appears to be caused by the shift in species composition from diatoms to nannoplankton (with higher $\mathrm{P}_{\mathrm{m}}^{\mathrm{B}}$ ) in the lower estuary. The greater variability in the summer regression line is indicative of other controls acting on $\int \mathrm{P}$. Possible explanations for this pattern include periodic nutrient limitation (our unpubl. data), zooplankton grazing (Herman et al. 1983), and changes in species composition from nannoplankton to diatoms.

\section{Annual area production}

Overall annual phytoplankton production in the Delaware Estuary was $307 \mathrm{~g} \mathrm{C} \mathrm{m}^{-2} \mathrm{yr}^{-1}$ over the 1981-1985 period, while yearly values ranged between 190 and $400 \mathrm{~g} \mathrm{C} \mathrm{m}^{-2} \mathrm{yr}^{-1}$ (1981 and 1985, respectively). These estimates fall toward the middle of the range reported for other estuarine systems (Table 1). In general, higher production estimates have been found under nutrient-enriched conditions similar to those of the Delaware Estuary. For example, production estimates for the lower Hudson Estuary (O'Reilly et al. 1976) and the nearshore waters of the New York Bight (Malone 1976) range from 370 to $820 \mathrm{~g} \mathrm{C} \mathrm{m}^{-2}$ $\mathrm{yr}^{-1}$. In contrast, turbid systems generally have low production rates $\left(<150 \mathrm{~g} \mathrm{C} \mathrm{m}^{-2} \mathrm{yr}^{-1}\right)$ when light appears limiting; examples include: Bristol Channel (Joint \& Pomroy 1981), Wassaw Estuary, Georgia (Turner et al. 1979), Peconic Bay Estuary, New York (Bruno et al. 1980), and San Francisco Bay (Cole \& Cloern 1984).

Compared with these other systems, the median range of annual phytoplankton production in the Delaware Estuary results from the interaction between high nutrient concentrations, which provide the system with a very high 'potential' for phytoplankton growth, and the factors that regulate light-availability. Differences in annual production in geographic regions along the Delaware Estuary provide evidence for the importance of light-limitation. Annual production varies from a minimum of $70 \mathrm{~g} \mathrm{C} \mathrm{m}^{-2} \mathrm{yr}^{-1}$ in the turbidity maximum to $392 \mathrm{~g} \mathrm{C} \mathrm{m}^{-2} \mathrm{yr}^{-1}$ in the central region of the lower estuary (Fig. 8). Because high turbidity limits production in the upper regions of the estuary, $>90 \%$ of the total annual production occurs in lower regions of the estuary, where freshwater nutrient concentrations have been diluted by mixing with low-nutrient salt water.

Because nutrient inputs and low turbidity waters are spatially separated, we have not observed noxious 


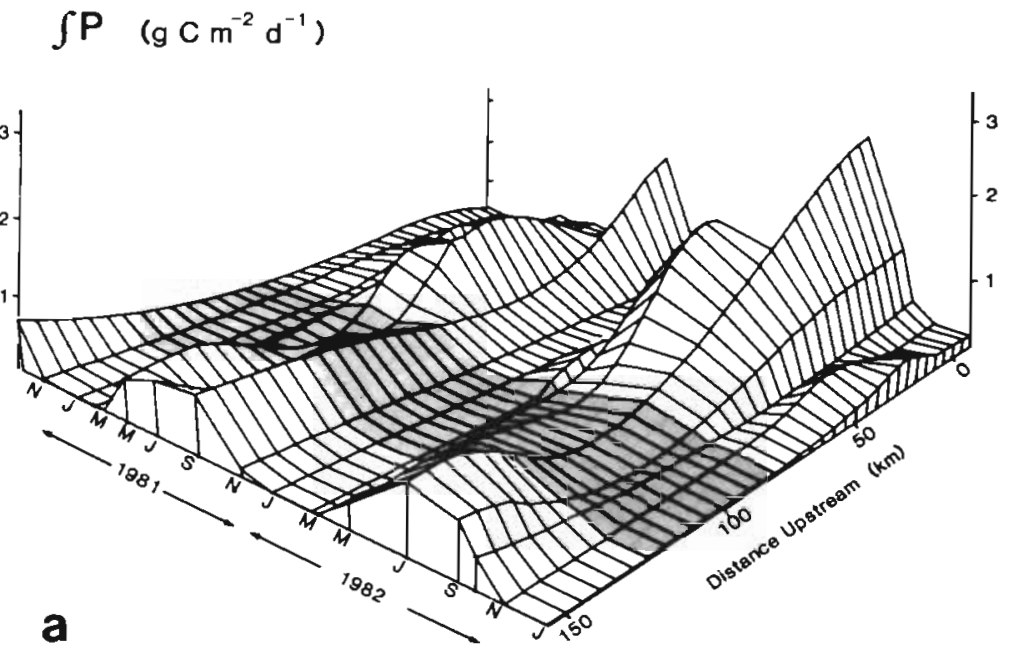

Fig. 5. Three-dimensional plots against distance upstream from mouth of Delaware Estuary and against time. (a) Areal primary production $\left(\int \mathrm{P}\right)$; (b) suspended sediment (seston). These were created by fitting cubic spline lcast squaie equations for individual cruises along the distance axis and then combining them for the time axis (Pennock 1983). Turbidity maximum indicated by shaded region

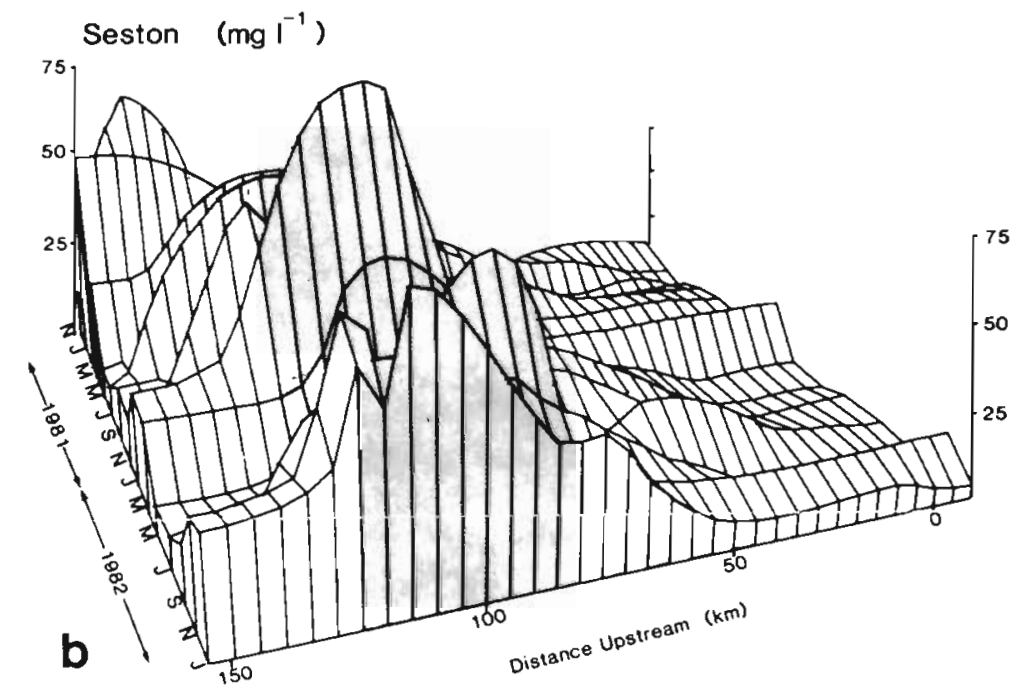

phytoplankton blooms in the Delaware such as those that are found in other nutrient-rich estuaries. In systems where nutrient inputs occur either in areas of low turbidity, such as the New York Bight (Malone 1976), or in areas with a shallow mixed surface-layer depth, as in Raritan Bay (Patten 1961) or the Potomac River Estuary (Heinle et al. 1980), much greater increases in phytoplankton production and biomass have been observed.

\section{Inter-annual variations}

Phytoplankton production in the estuary displayed marked inter-annual variability over the study period (Fig. 3). The factors regulating the timing and magnitude of variations in $\int P$ are difficult to delineate, and yet most important to the overall production of the estuary. The timing and intensity of both the summer production maximum in the upper estuary (Station SO) and the spring bloom in mid-estuary (Station CL) can be predicted using a model describing light availability (Pennock 1985), and a knowledge of chlorophyll specific production rates. The factors regulating interannual variability in production in the lower estuary, however, are more complex. At this time, despite extensive sampling over many years, it is unclear how factors such as temperature, physical mixing processes, and variability in nutrient loading combine to determine the observed patterns in the lower estuary.

\section{Spatial and temporal variations in photosynthetic parameters}

Finally, it is valuable to address the role that physiological adaptation to light-limited conditions could play in affecting phytoplankton production in estuarine environments. Two questions of particular 

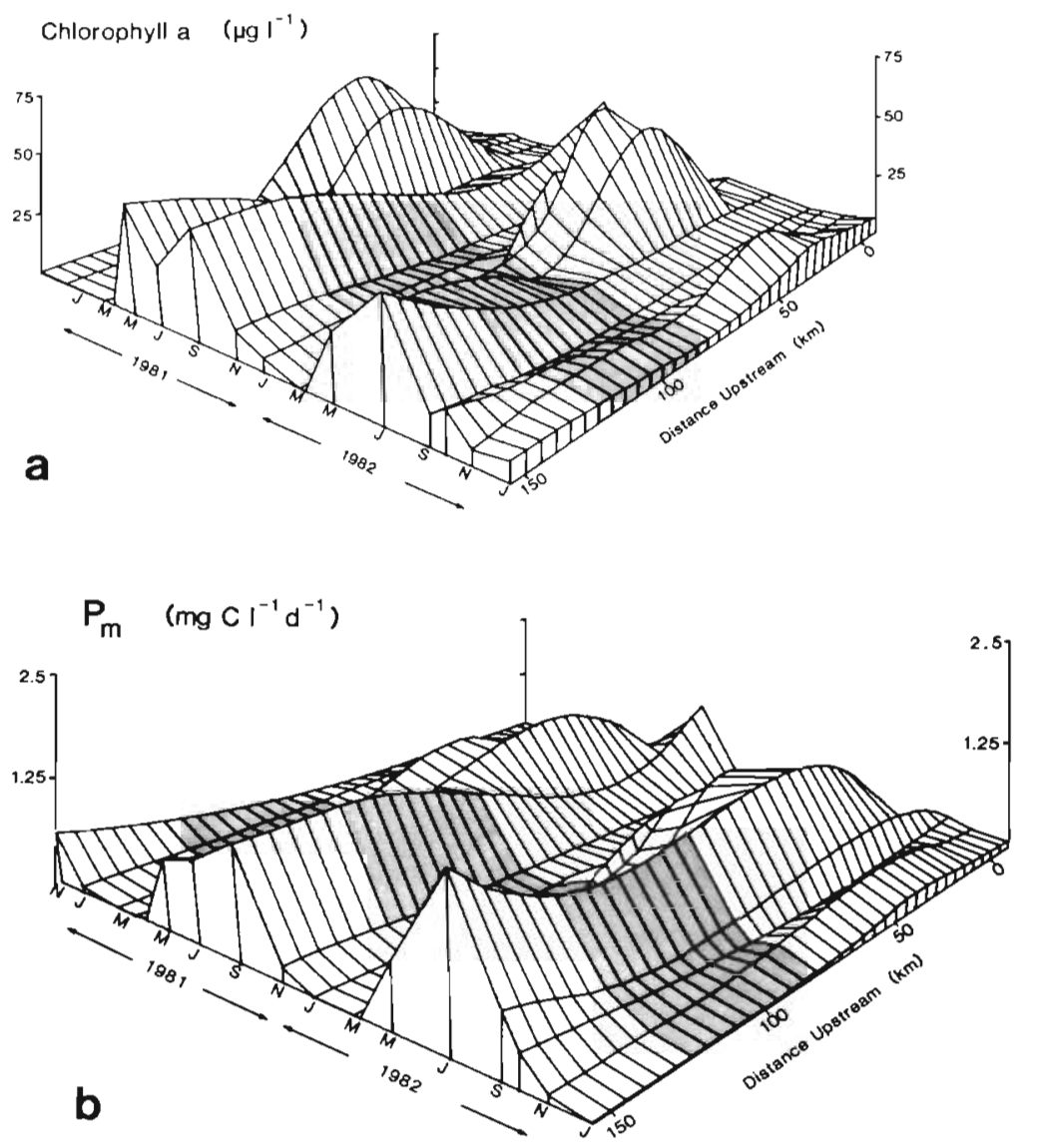

Fig. 6. Three-dimensional plots against distance upstream from mouth of Delaware Estuary and against time. (a) Phytoplankton biomass, estimated as chlorophyll; (b) maximum primary production per unit volume $\left(\mathrm{P}_{\mathrm{m}}\right)$. Turbidity maximum indicated by shaded region

interest are: (1) do estuarine phytoplankton exhibit variations in photosynthetic parameters that indicate adaptation to low-light environments? and (2) do environmentally induced variations in these parameters affect the overall production of the system?

Light-saturated photosynthesis per unit chlorophyll,

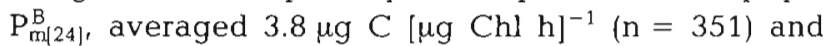
displayed large seasonal variations. Seasonal averages were 1.9, 1.4, and $7.0 \mu \mathrm{g} \mathrm{C}[\mu \mathrm{g} \mathrm{Chl} \mathrm{h}]^{-1}$, for fall/winter, spring, and summer, respectively. Overall, the range of $P_{m|24|}^{B}$ values for the Delaware Estuary is similar to ranges of values reported for other estuarine systems (Table 2), although the mean value is lower than values reported for other nutrient-rich systems. Primary factors affecting $P_{\mathrm{m}|24|}^{B}$ in the Delaware Estuary appear to be temperature and species composition. Both factors are related to the elevated $\mathrm{P}_{\mathrm{m}[24]}^{\mathrm{B}}$ observed during summer. The apparently lower average $\mathrm{P}_{\mathrm{m}|24|}^{\mathrm{B}}$ compared to other systems may be partially the function of the large number of samples collected at low water temperature and the overall importance of large diatoms in this estuary over the entire seasonal cycle as compared with many other systems.

The highest values of $\mathrm{P}_{\mathrm{m}\{24\}}^{\mathrm{B}}$ in the Delaware Estuary are related exponentially to temperature (Fig. 9a) as is to be expected on theoretical grounds and from earlier work (Eppley 1972). However, we record many values below this theoretical maximum, particularly at high temperatures.

In addition to changes in species composition, such a depression in $\mathrm{P}_{\mathrm{m}}^{\mathrm{B}}$ may also be the result of increased cellular chlorophyll content resulting from photoadaptation to the low light environment. Such a response is well documented in phytoplankton populations found in constant low light conditions; for example, the subsurface chlorophyll maximum (Platt \& Jassby 1976, Falkowski 1980, Prezelin 1981, Harding et al. 1983). If chlorophyll biosynthesis were being stimulated as a result of low-light conditions in the estuary, then $\mathrm{P}_{\mathrm{m}[24]}^{B}$ would be expected to decrease as average photic zone light energy decreased. This response, which has been seen in populations exposed to continuous low-light conditions, was not observed in the Delaware Estuary (Fig. 9b). It appears that stimulation of chlorophyll synthesis under light-limited conditions is suppressed by the periodic exposure to high surface light intensities under well-mixed conditions such as those encountered in the estuary. This is consistent with results found elsewhere in which the vertical mixing rate is faster than the period required for the photoadaptive response (Falkowski 1983).

The initial slope of the $P / I$ curve, $\alpha_{\{24\}}^{8}$, averaged 


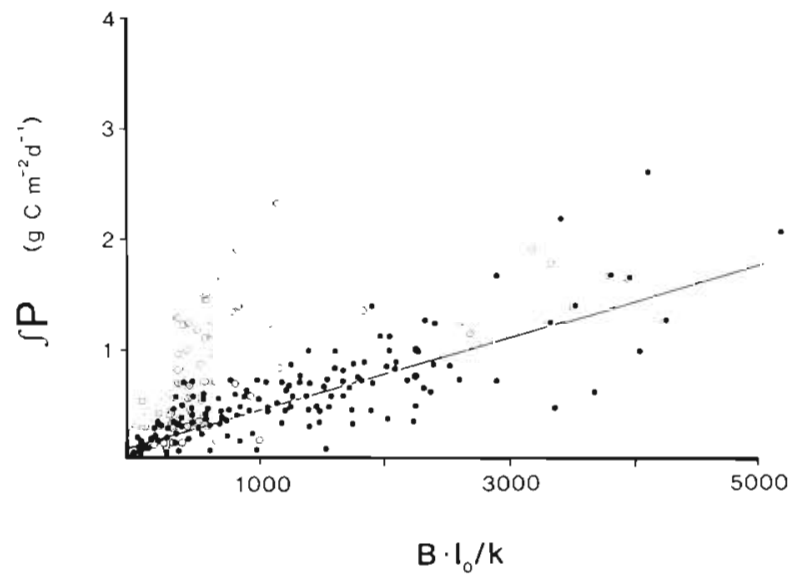

Fig. 7. Regression of $\int P$ versus $B I_{0} / k$, a parameter describing light availability and phytoplankton biomass, for stations in the Delaware Estuary. Data are grouped into non-summer periods $\left(\bullet ; r^{2}=0.68\right)$ and summer periods $\left(0 ; r^{2}=0.42\right)$

$0.031 \mu \mathrm{g} \mathrm{C}[\mu \mathrm{g} \mathrm{Chl} \mathrm{h}]^{-1}\left[\mu \mathrm{E} \mathrm{m}^{-2} \mathrm{~s}^{-1}\right]^{-1}$, and was similar to estimates for other estuaries (Table 2). Although values ranged from $<0.01$ to $0.13 \mu \mathrm{g} \mathrm{C}[\mu \mathrm{g} \mathrm{Chl} \mathrm{h}]^{-1}[\mu \mathrm{E}$ $\mathrm{m}^{-2} \mathrm{~s}^{-1} \mathrm{j}^{-1}$, these variations were of the same magnitude during any one sampling period along the salinity gradient as they were seasonally. There was no relation between $\alpha_{|24|}^{\mathrm{B}}$ and mean light intensity in the mixed-layer in the Delaware Estuary (Fig. 10). As with $\mathrm{P}_{\mathrm{m}[24]}^{\mathrm{B}}$, such a relation would be expected if photoadaptation were occurring.

As a result of the large seasonal variation in $\mathrm{P}_{\mathrm{m}[24]}^{\mathrm{B}}$ and minimal variation in $\alpha_{124}^{B}$, the light intensity at

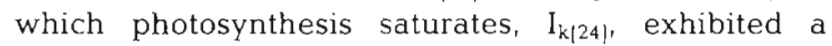
linear increase with temperature (Fig. 11a). Mean $I_{k[24]}$ values for fall/winter, spring, and summer periods (61, 68, and $218 \mu \mathrm{E} \mathrm{m} \mathrm{m}^{-2} \mathrm{~s}^{-1}$, respectively), resulted in an annual average of $126 \mu \mathrm{E} \mathrm{m}^{-2} \mathrm{~s}^{-1}$. This value is substantially lower than $358 \mu \mathrm{E} \mathrm{m}^{-2} \mathrm{~s}^{-1}$ found by Fisher et al. (1982) for the South River, Neuse River, and Newport River estuaries in North Carolina, but is comparable to 100 to $150 \mu \mathrm{E} \mathrm{m} \mathrm{m}^{-2} \mathrm{~s}^{-1}$ determined during lightlimited turbidostat culture with Dunaliella tertiolecta (Falkowski 1980). Although $I_{k}$ has been used extensively as an indicator of light-adapted state (Harris 1978), it did not decrease, as might have been expected, as mean mixed surface-layer photic energy decreased (Fig. $11 \mathrm{~b}$ ).

Ryther \& Menzel (1959) suggested that 'shade' adaptation occurs only when low light conditions are stable (e.g. below the pycnocline) and that well-mixed conditions promote 'sun' adaptation, even in winter periods when overall production is limited by low levels of incident light. These results support their hypothesis in

Table 1. Daily and annual primary production in selected estuarine and coastal ecosystems. Daily production $=\mathrm{g} C \mathrm{~m}^{-2} \mathrm{~d}^{-1}$; annual production $=\mathrm{g} \mathrm{C} \mathrm{m}^{-2} \mathrm{yr}^{-1}$

\begin{tabular}{|c|c|c|c|}
\hline \multirow[t]{2}{*}{ Region } & \multicolumn{2}{|c|}{ Production } & \multirow[t]{2}{*}{ Source } \\
\hline & Daily & Annual & \\
\hline Hudson Estuary & & 820 & O'Reilly et al. (1976) \\
\hline Great South Bay, New York & & 450 & Lively et al. (1983) \\
\hline Hudson Estuary: & & & \\
\hline New York Bight apex & $0.1-6.0$ & 370 & Malone (1976) \\
\hline lower bay & $0.1-2.2$ & 200 & Malone (1977) \\
\hline Chesapeake Bay & $0.1-3.3$ & & Flemer (1970) \\
\hline Pamlico River, N. Carolina & $0.1-3.3$ & 200 & $\begin{array}{l}\text { Kuenzler et al. (1979) } \\
\text { Davis et al. (1978) }\end{array}$ \\
\hline Narragansett Bay, Rhode Island & $0.2-3.2$ & 220 & Smayda (1973) \\
\hline Peconic Bay, New York & & $162-213$ & Bruno et al. (1980) \\
\hline Long Island Sound & & 166 & Ryther \& Yentsch (1958) \\
\hline Patuxent River, Maryland & $0.1-1.5$ & & Flemer et al. (1970) \\
\hline Raritan Bay, New Jersey & $0.1-1.5$ & & Patten (1961) \\
\hline $\begin{array}{l}\text { San Francisco Bay: } \\
\text { upper bay } \\
\text { lower bay }\end{array}$ & $\begin{array}{l}0.1-0.5 \\
0.1-0.9\end{array}$ & 130 & $\begin{array}{l}\text { Peterson (1979) } \\
\text { Cloern (1979) } \\
\text { Cole \& Cloern (1984) }\end{array}$ \\
\hline Wassaw Estuary, Georgia & $0.9-2.2$ & 90 & Turner et al. (1979) \\
\hline $\begin{array}{l}\text { Delaware Estuary: } \\
\text { upper estuary } \\
\text { lower estuary }\end{array}$ & $\begin{array}{l}0.1-1.3 \\
0.1-4.2\end{array}$ & 307 & Present study \\
\hline
\end{tabular}




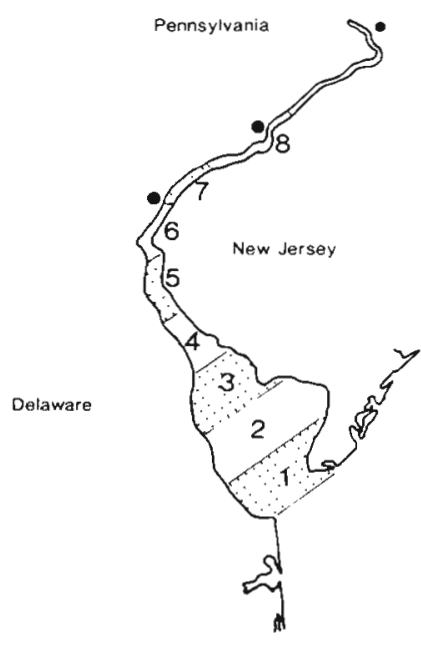

\begin{tabular}{ccc}
$\begin{array}{c}\text { Annual Areal Production } \\
\left(\mathrm{gm} \mathrm{C} \mathrm{m}^{-2} \text { year }^{-1}\right)\end{array}$ & $\begin{array}{c}\text { \%of otal } \\
\text { estuary production }\end{array}$ \\
\hline 8 & 149 & 1 \\
7 & 97 \\
6 & 70 \\
5 & 102 & 1 \\
4 & 200 & 1 \\
3 & 392 & 5 \\
2 & 368 & 22 \\
1 & 273 & 44 \\
\hline
\end{tabular}

average $=307$
Fig. 8. Annual areal production of phytoplankton in the Delaware Estuary. The estuary was divided into 8 regions, and area-weighted averages for each calculated. Data from sampling between October 1980 and August 1985

Table 2. $P_{\mathrm{m}}^{\mathrm{B}}\left(\mu \mathrm{g} \mathrm{C}[\mu \mathrm{g} \mathrm{Chl} \mathrm{h}]^{-1}\right)$ and $\alpha^{\mathrm{B}}\left(\mu \mathrm{g} \mathrm{C}[\mu \mathrm{g} \mathrm{Chl} \mathrm{h}]^{-1}\left[\mu \mathrm{E} \mathrm{m}^{-2} \mathrm{~s}^{-1}\right]^{-1}\right)$ for selected coastal and estuarine systems. Results reported as mean (range)

\begin{tabular}{|c|c|c|c|}
\hline Region & $\mathrm{P}_{\mathrm{m}}^{\mathrm{B}}$ & $\alpha^{\mathrm{B}}$ & Source \\
\hline Oregon coast & $\begin{array}{c}8.6 \\
(6-21)\end{array}$ & & Curl \& Small (1965) \\
\hline Nova Scotia coast: $1 \mathrm{~m}$ & $\begin{array}{c}5.8 \\
(0.9-19.1)\end{array}$ & $\begin{array}{c}0.059 \\
(0.012-0.154)\end{array}$ & Platt \& Jassby (1976) \\
\hline Bedford Basin, Novia Scotia & $\begin{array}{c}5.5 \\
(2.0-13.1)\end{array}$ & & Harrison \& Platt (1980) \\
\hline Bedford Basin, Novia Scotia & $\begin{array}{c}4.9 \\
(2.0-8.4)\end{array}$ & $\begin{array}{c}0.034 \\
(0.020-0.064)\end{array}$ & Cote \& Platt (1983) \\
\hline $\begin{array}{c}\text { New York Bight: } \\
\text { nanno- } \\
\text { net- }\end{array}$ & $\begin{array}{c}11.3 \\
(2.0-30.8) \\
8.1 \\
(0.3-24.0)\end{array}$ & $\begin{array}{c}0.06 \\
(0.011-0.153) \\
0.05 \\
(0.002-0.154)\end{array}$ & Malone \& Neale (1981) \\
\hline $\begin{array}{l}\text { Newport, Neuse \& } \\
\text { South Rivers, N. Carolina }\end{array}$ & $\begin{array}{c}7.5 \\
(\sim 2.4-\sim 12.0)\end{array}$ & & Fisher et al. (1982) \\
\hline $\begin{array}{l}\text { Beaufort Channel, } \\
\text { N. Carolina }\end{array}$ & $\begin{array}{c}6.9 \\
(1.9-19.8)\end{array}$ & & Williams \& Murdoch (1966) \\
\hline $\begin{array}{l}\text { Great South Bay, } \\
\text { New York }\end{array}$ & $\begin{array}{c}5.0 \\
(1.0-13.0)\end{array}$ & & Lively et al. (1983) \\
\hline $\begin{array}{l}\text { Narragansett Bay, } \\
\text { Rhode Island }\end{array}$ & $\begin{array}{c}3.9 \\
(1.3-9.5)\end{array}$ & & Durbin et al. (1974) \\
\hline Chesapeake Bay & $\begin{array}{c}3.9 \\
(1.3-10.3)\end{array}$ & & Flemer $(1970)$ \\
\hline $\begin{array}{l}\text { Bristol Channel, } \\
\text { U.K. }\end{array}$ & $(-1.0-<7.0)$ & & Joint \& Pomroy (1981) \\
\hline $\begin{array}{l}\text { Fraser River } \\
\text { Estuary }\end{array}$ & $\begin{array}{c}2.1 \\
(0.9-4.8)\end{array}$ & & Takahashi et al. (1973) \\
\hline Delaware Estuary & $\begin{array}{c}3.8 \\
(1.0-22.7)\end{array}$ & $\begin{array}{c}0.031 \\
(0.020-0.064)\end{array}$ & Present study \\
\hline
\end{tabular}


that light-limited phytoplankton did not display photoadaptive responses in the well-mixed water-column of the Delaware Estuary.
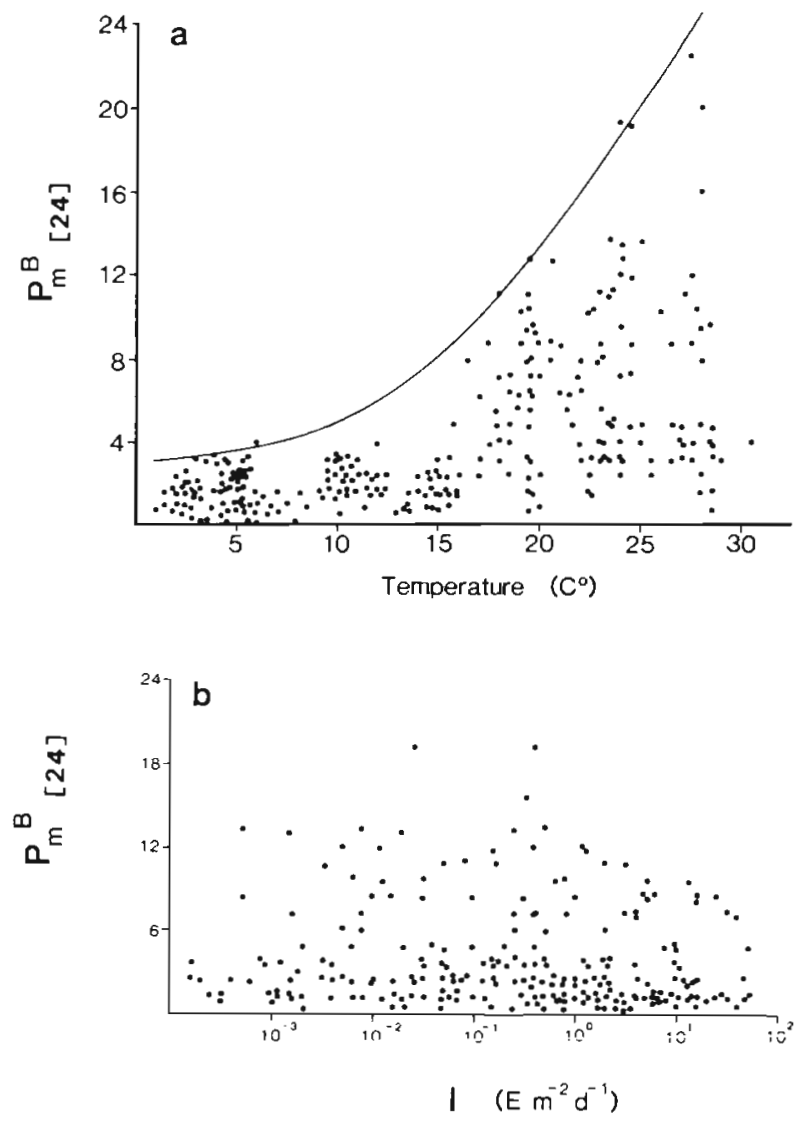

Fig. 9. Light saturated photosynthesis per unit chlorophyll $\left(\mathrm{P}_{\mathrm{m}(24)}^{\mathrm{B}}\right)$ in units of $\mu \mathrm{g} \mathrm{C}[\mu \mathrm{g} \mathrm{Chl} \mathrm{h}]^{-1}$ as a function of temperature (a) and of light intensity in the mixed layer (I) (b). Data from the entire Delaware Estuary 1980-1982. Curve on (a) is an empirically derived maximum line

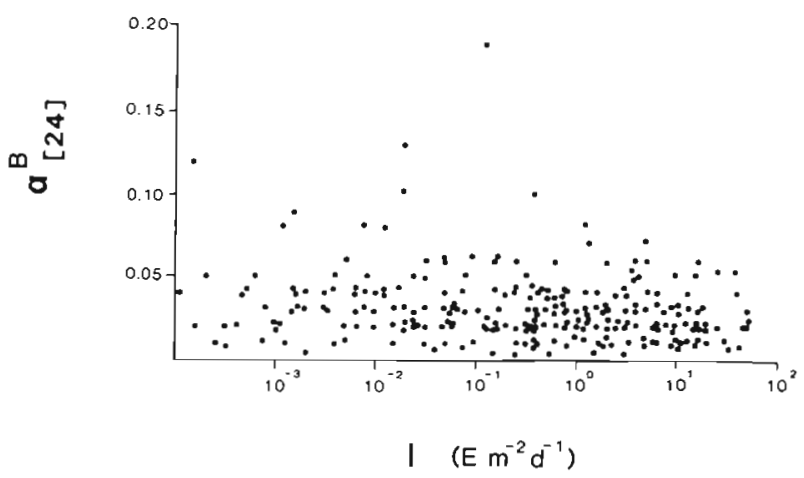

Fig. 10. Initial slope of the P/I curve $\left(\alpha_{24}^{B}\right)$ in units of $\mu \mathrm{g} C[\mu \mathrm{g}$ $\mathrm{Chl} \mathrm{h}]^{-1}\left[\mu \mathrm{E} \mathrm{m}^{-2} \mathrm{~s}^{-1}\right]^{-1}$ versus light intensity in the mixed layer (I) for samples from the Delaware Estuary taken from $1980-1982$
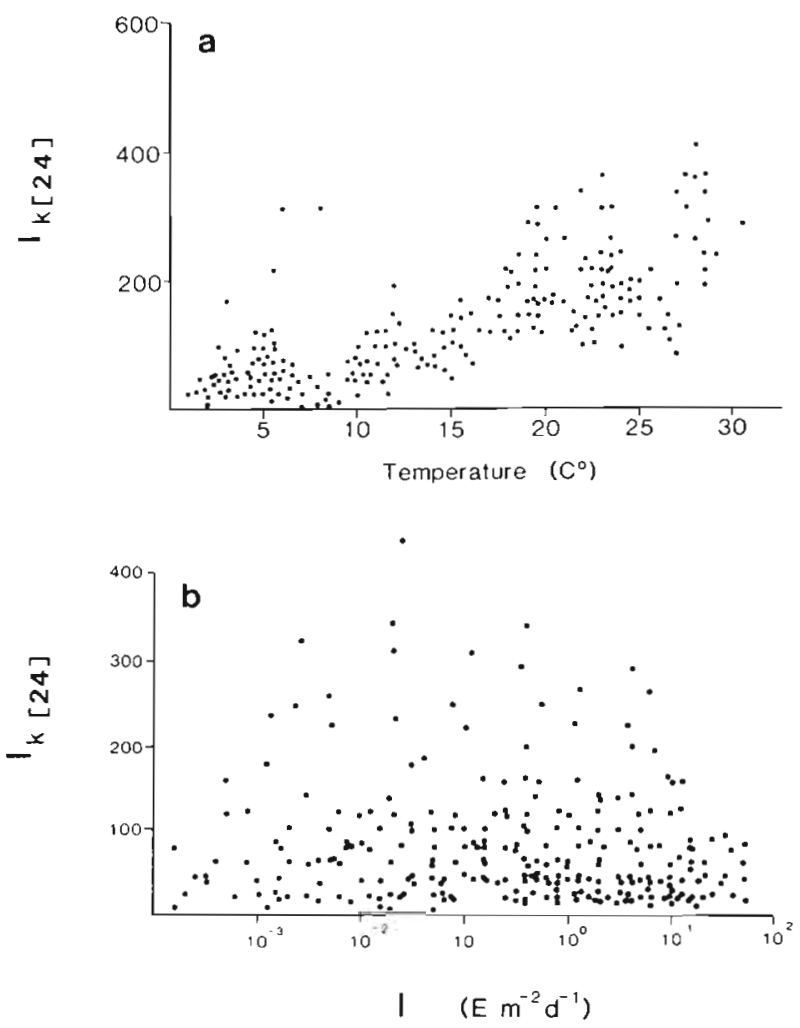

Fig. 11. Light intensity at which photosynthesis saturates $\left(I_{k}\right)$ in $\mu \mathrm{E} \mathrm{m}^{-2} \mathrm{~s}^{-1}$ as a function of temperature (a) and of light intensity in the mixed layer (I) (b). Data from sampling throughout the Delaware Estuary in 1980-1982

\section{CONCLUSIONS}

Phytoplankton production in the Delaware Estuary averaged $307 \mathrm{~g} \mathrm{C} \mathrm{m}^{-2} \mathrm{yr}^{-1}$. This average is the net result of nutrient-rich conditions, which afford high potential for growth in the system, and turbid conditions, which impose light-limitation to growth. These conflicting influences result in an annual production that is moderate when compared to published production results in other nutrient-enriched estuarine systems. The proximity of the turbidity maximum just downstream from the major nutrient inputs in the freshwater region appears to maintain phytoplankton biomass below the nuisance levels encountered in other nutrient-enriched estuaries. When phytoplankton growth does occur, downstream from the turbidity maximum, nutrient concentrations are sufficiently diluted by mixing with low-nutrient ocean water that massive chlorophyll concentrations are not observed.

Maximum light-saturated production per unit chlorophyll occurs in summer and is comparable to maximum rates in other systems, although the annual average is slightly lower than average for other nutrient-rich systems. The slightly low average is not 
related to increased chlorophyll synthesis resulting from photoadaptation. We suggest that although phytoplankton in a well-mixed estuary like the Delaware are light-limited, periodic transport into high-light surface waters alters the photoadaptive responses that occur under constant low-light conditions. As a result, variations in $\mathrm{P}_{\mathrm{m}}^{\mathrm{B}}$ caused by photoadaptation do not affect the overall production of phytoplankton in the estuary. In contrast, increases in $\mathrm{P}_{\mathrm{m}}^{\mathrm{B}}$ associated with nannoplankton populations during the summer are important to the production characteristics of the estuary.

Acknowledgements. Technical aid of L. A. Cifuentes, R. B. Coffin, C. H. Culberson, A. C. Frake, D. L. Murphy, T. F. Pfeiffer, S. E. Pike, and J. M. Tramontano, and ship support of Captain J. H. Gay and the crew of the R/V Cape Henlopen are gratefully acknowledged. Thanks are also extended to J. E. Cloern, L. E. Harding and T. R. Fisher for critical reviews of an earlier version of the manuscript. This research was supported by grants to J. H. Sharp from the Delaware River and Bay Authority and from the Office of Sea Grant [NA80AA-D-00106] of the U.S. National Oceanic and Atmospheric Administration. The manuscript is part of a dissertation submitted by Jonathan $\mathrm{R}$. Pennock to the University of Delaware in partial fulfillment of the Ph.D. degree in Oceanography.

\section{LITERATURE CITED}

Boynton, W. R., Kemp, W. M., Keefe, C. W. (1982). A comparative analysis of nutrients and other factors influencing estuarine phytoplankton production. In: Kennedy, V. S. (ed.) Estuarine comparisons. Academic Press, London, p. $69-90$

Bruno, S. F., Staker, R. D., Sharma, G. M. (1980). Dynamics of phytoplankton productivity in the Peconic Bay Estuary, Long Island. Estuar. coast. mar. Sci. 10: 247-263

Carpenter, E. J., Lively, J. S. (1980). Review of estimates of algal growth using 14-C tracer techniques. In: Falkowski, P. G. (ed.) Primary productivity in the sea. Environmental Science Research. Plenum Press, London, p. 161-178

Carpenter, J. H. (1965). The Chesapeake Bay Institute technique for the Winkler dissolved oxygen method. Limnol. Oceanogr. 10: 141-143

Cloern, J. E. (1979). Phytoplankton ecology of the San Francisco Bay system: the statues of our current understanding. In: Conomos, J. T. (ed.) San Francisco Bay: the urbanized estuary. Allen Press, San Francisco, p. 247-264

Cloern, J. E. (1984). Temporal dynamics and ecological significance of salinity stratification in an estuary (South San Francisco Bay, USA). Oceanological Acta 7: 137--141

Cloern, J. E., Cole, B. E., Wong, R. L. J., Alpine, A. E (1985). Temporal dynamics of estuarine phytoplankton: A case study of San Francisco Bay. In: Cloern, J. E., Nichols, F. H. (ed.) Temporal dynamics of an estuary: San Francisco Bay. Dr. W. Junk Publishers, Boston, p. 153-176

Cole, B. E., Cloern, J. E. (1984). Significance of biomass and light availability to phytoplankton productivity in San Francisco Bay. Mar. Ecol. Prog. Ser 17: 15-24

Cote, B., Platt, T (1983). Day-to-day variations in the springsummer photosynthetic parameters of coastal marine phytoplankton. Limnol. Oceanogr. 28: 320-344
Curl H. C., Small, L. F. (1965). Variations in photosynthetic ratios in natural marine phytoplankton communities. Limnol. Oceanogr. 10 (Suppl.): R67-R73

Davis, G. J., Bunison, M. M., Burke, W. A. (1978). Organic carbon and deoxygenation in the Pamlico River Estuary. Water Research Institute of the University of North Carolina, Report No. 131. University of North Carolina. Raleigh, N.C.

Durbin, E. G., Krawiec, R. W., Smayda, T. J. (1974). Seasonal studies on the relative importance of different size fractions of phytoplankton in Narragansett Bay. Mar. Biol. 32: $271-287$

Edmond, J. M. (1970). High precision determination of titration alkalinity and total carbon dioxide content of sea water by potentiometric titration. Deep Sea Res. 17: $737-750$

Eppley, R. W. (1972). Temperature and phytoplankton growth int he sea. Fish. Bull. U.S. 70: 1063-1085

Eppley, R. W., Sharp, J. H. (1975). Photosynthetic measurements in the central North Pacific: The dark loss of carbon in 24-h incubations. Limnol. Oceanogr. 20: 981-987

Falkowski, P. G. (1980). Light-shade adaptation in marine phytoplankton. In: Falkowski, P. G. (ed.) Primary productivity in the sea. Environmental Science Research. Plenum Press, New York, p. 99-119

Falkowski, P. G. (1983). Light-shade adaptation and vertical mixing of marine phytoplankton: A comparative field study. J. mar. Res. 41: 215-237

Fisher, T. R., Carlson, P. R., Barber, R. T. (1982). Carbon and nitrogen primary productivity in three North Carolina estuaries. Estuar. coast. Shelf Sci. 15: 621-644

Fitzwater, S. E., Knauer, G. A., Martin, J. H. (1982). Metal contamination and its effect on primary production measurements. Limnol. Oceanogr. 27: 544-551

Flemer, D. A. (1970). Primary production in the Chesapeake Bay. Chesapeake Sci. 11: 117-129

Flemer, D. A., Hamilton, D. H., Keefe, C. W., Mihursky, J. A. (1970). The effects of thermal loading and water quality on estuarine primary production. Chesapeake Biological Laboratory, Ref. No. 71-6

Harding, L. W., Meeson, B. W., Tyler, M. A. (1983). Photoadaptation and diel periodicity of photosynthesis in the dinoflagellate Prorocentrum mariae-lebouriae. Mar. Ecol. Prog. Ser. 13: 73-85

Harris, G. P. (1978). Photosynthesis, productivity and growth: The physiological ecology of phytoplankton. Arch. Hydrobiol. Beih. Ergeb. Limnol. 10: 1-71

Harrison, W. G., Platt, T. (1980). Variations in assimilation number of coastal marine phytoplankton: Effects of environmental covariates. J. Plankton Res, 2: 249-260

Head, A. (1976). Primary production in an estuarine environment: A comparison of in situ and simulated in situ $14 \mathrm{C}$ techniques. Estuar. coast. mar. Sci. 4: 575-578

Heinle, D. R., D'Elia, C. F., Taft, J. L., Wilson, J. S., ColeJones, M., Caplins, A. B., Cronin, L. E. (1980). Historical review of water quality and climatic data from Chesapeake Bay with emphasis on effects of enrichment. Chesapeake Res. Consortium, Inc.

Herman, S. S., Hargraves, B. R., Lutz, R. A., Fritz, L. W., Epifanio, C. E. (1983). Zooplankton and parabenthos. In: Sharp, J. H. (ed.) The Delaware Estuary: research as background for management and development. Univ. of Delaware \& New Jersey. Mar. Sci. Consortium, p. 157-168

Jaworski, N. A. (1981). Sources of nutrients and the scale of eutrophication problems in estuaries. In: Nielson, B. J., Cronin, L. E. (ed.) Estuaries and nutrients. Humana Press, Clifton, p. 83-110 
Joint, I. R., Pomroy, A. J. (1981). Primary production in a turbid estuary. Estuar. coast. Shelf Sci. 13: 303-316

Kuenzler, E. J., Stanley, D. W., Koenings, J. P. (1979). Nutrient kinetics of phytoplankton in the Pamlico River, North Carolina River, North Carolina. Water Resources Research Institute, Report No. 139. University of North Carolina. Raleigh, N.C

Lipschultz, F., Wofsy, S. C., Fox, L. E. (1985). The effects of light and nutrients on rates of ammonium transformation in a eutrophic river. Mar. Chem. 16: 329-341

Lively, J. S., Kaufman, Z., Carpenter, E. J. (1983). Phytoplankton ecology of a barrier island estuary: Great South Bay, New York. Estuar. coast. Shelf Sci. 16: 51-68

Malone, T. C. (1976). Phytoplankton productivity in the apex of the New York Bight: Environmental regulation of productivity/chlorophyll a. In: Gross, M. G. (ed.) The Middle Atlantic Shelf and New York Bight. Limnol. Oceanogr. Special Symposia Vol. 2: 260-272

Malone, T. C. (1977). Environmental regulation of phytoplankton productivity in the lower Hudson Estuary. Estuar. coast. mar. Sci. 5: 157-171

Malone, T. C., Neale, P. J. (1981). Parameters of light-dependent photosynthesis for phytoplankton size fractions in temperate estuarine and coastal environments. Mar. Biol 61: 289-297

O'Reilly, J. E., Thomas, J. P., Evans, C. (1976). Annual primary production (nannoplankton, netplankton, dissolved organic matter) in the lower New York Bay. In: McKeon, W. H., Lauer, G. J. (ed.) Fourth symposium on Hudson River ecology. Hudson River Environ. Society, New York

Patten, B. (1961). Plankton energetics of Raritan Bay. Limnol. Oceanogr. 4: 369-387

Pennock, J. R. (1983). Regulation of phytoplankton carbon and nitrogen production in the Delaware Estuary. Ph.D. dissertation, University of Delaware

Pennock, J. R. (1985). Chlorophyll distributions in the Delaware Estuary: Regulation by light-limitation. Estuar. coast. Shelf Sci, 21: 711-725

Peterson, B. J. (1980). Aquatic productivity in the $14 \mathrm{C}-\mathrm{CO}_{2}$ method: A history of the productivity problem. Ann. Rev. Ecol. Syst. 11: 359-385

Peterson, D. H. (1979). Sources and sinks of biologically reactive oxygen, carbon, nitrogen, and silica in Northern San Francisco Bay. In: Conomos, T. J. (ed.) San Francisco Bay, The urbanized estuary. Allen Press, San Francisco, p. $175-193$

Platt, T., Jassby, A. D. (1976). The relationship between photosynthesis and light for natural assemblages of coastal marine phytoplankton. J. Phycol. 12: 421-430

Prezelin, B. B. (1981). Light reactions in photosynthesis. In Platt, T. (ed.) Physiological bases of phytoplankton ecology. Can. J. Fish. Aquat. Sci. 210: 1-43

Riley, G. A. (1967). The plankton of estuaries. In: Lauff, G. A. (ed.) Estuaries. AAAS Publ., Washington D. C., p. 316-328
Ryther, J. H., Dunstan, W. M. (1971). Nitrogen, phosphorus, and eutrophication in the coastal marine environment Science 171: 1008-1013

Ryther, J. H., Menzel, D. W. (1959). Light adaptation by marine phytoplankton. Limnol. Oceanogr. 4: 492-497

Ryther, J. H., Yentsch, C. S. (1958). Primary production of continental shelf waters off New York. Limnol. Oceanogr. 3: $327-335$

Smayda, T. J. (1973). A survey of phytoplankton dynamics in the coastal waters from Cape Hatteras to Nantucket. In: Salia, S. B. (ed.) Coastal and offshore environmental inventory, Cape Hatteras to Nantucket Shoals. Univ. Rhode Island Mar. Publ. Ser., p. 3-1 to 3-100

Sharp, J. H., Church, T. M. (1981). Biochemical modeling in coastal waters of the middle Atlantic states. Limnol. Oceanogr. 26: 843-854

Sharp, J. H., Culberson, C. H., Church, T. M. (1982). The chemistry of the Delaware Estuary: general considerations. Limnol. Oceanogr. 27: 1015-1028

Sharp, J. H., Pennock, J. R., Church, T. M., Tramontano, J. M., Cifuentes, L. A. (1984). The estuarine interaction of nutrients, organics, and metals: a case study in the Delaware Estuary. In: V. S. Kennedy (ed.) The estuary as a filter. Academic Press, New York, p. 241-258

Sharp, J. H., Cifuentes, L. A., Coffin, R. B., Pennock, J. R., Wong, K.-C. (1986). The influence of river variability on the circulation, chemistry, and microbiology of the Delaware Estuary. Estuaries (in press)

Strickland, J. D. H., Parsons, T. R. (1972). A practical handbook of seawater analysis. Bull. Fish. Res. Bd Can. 167 311

Takahashi, M., Fujii, K., Parsons, T. R. (1973). Simulation study of phytoplankton photosynthesis and growth in the Fraser River Estuary. Mar. Biol. 19: 102-116

Turner, R. E., Woo, S. W., Hitts, H. R. (1979). Phytoplankton production in a turbid, temperate salt marsh estuary Estuar. coast. mar. Sci. 9: 603-613

Tyler, M. A., Seliger, H. H. (1978). Annual subsurface transport of a red tide dinoflagellate to its bloom area: water circulation patterns and organism distributions in the Chesapeake Bay. Limnol. Oceanogr. 23: 227-246

Williams, R. B. (1972). Annual phytoplankton production in a system of shallow temperate estuaries. In: Chabreck, R. H (ed.) Proceedings of the Coastal Marsh and Estuary Management Symposium. Louisiana State Univ. Press, Baton Rouge, p. 59-89

Williams, R. B., Murdoch, M. B. (1966). Phytoplankton production and chlorophyll concentration in the Beaufort Channel, North Carolina, Limnol. Oceanogr. 11: 73-82

Wofsy, S. C. (1983). A simple model to predict extinction coefficients and phytoplankton biomass in eutrophic waters. Limnol. Oceanogr. 28: 1144-1155 